\title{
Integrated Effect of Plant Density, N Rates and Irrigation Regimes on the Biomass Production, N Content, PAR Use Efficiencies and Water Productivity of Rice Under Irrigated Semiarid Environment
}

\author{
Shakeel AHMAD ${ }^{1}$, Mirza HASANUZZAMAN²* \\ ${ }^{1}$ Bahauddin Zakariya University, Department of Agronomy, Multan-60800, Pakistan \\ ${ }^{2}$ Sher-e-Bangla Agricultural University, Department of Agronomy, Faculty of Agriculture, \\ Dhaka-1207,Bangladesh; mhzsauag@yahoo.com (*corresponding author)
}

\begin{abstract}
Two field experiments were conducted for two years (2000 and 2001) at Agronomic Research Area, University of Agriculture Faisalabad (UAF), Pakistan. There were 15 treatment combinations for experiment-I having three plant densities, viz., one seedling hill ${ }^{-1}$ $\left(\mathrm{PD}_{1}\right)$, two seedlings hill-1 $\left(\mathrm{PD}_{2}\right)$ and three seedlings hill'-1 $\left(\mathrm{PD}_{3}\right)$ and five nitrogen rates, viz., $0,\left(\mathrm{~N}_{0}\right) ; 50,\left(\mathrm{~N}_{50}\right) ; 100,\left(\mathrm{~N}_{100}\right) ; 150$, $\left(\mathrm{N}_{150}\right) ;$ and $200\left(\mathrm{~N}_{200}\right) \mathrm{kg} \mathrm{N} \mathrm{ha}^{-1}$. Experiment-II also included 15 treatments having three plant densities, viz., one seedling hill ${ }^{-1}\left(\mathrm{PD}_{1}\right)$, two seedlings hill $^{-1}\left(\mathrm{PD}_{2}\right)$ and three seedlings hill ${ }^{-1}\left(\mathrm{PD}_{3}\right)$ and five irrigation regimes, viz., $62.5 \mathrm{~cm}\left(\mathrm{I}_{1}\right), 77.5 \mathrm{~cm}\left(\mathrm{I}_{2}\right), 92.5 \mathrm{~cm}\left(\mathrm{I}_{3}\right), 107.5 \mathrm{~cm}\left(\mathrm{I}_{4}\right)$, and $122.5 \mathrm{~cm}\left(\mathrm{I}_{5}\right)$. A randomized complete block design (RCBD) was employed with three repetitions. The results for experiment-I revealed that the highest biomass $\left(1438 \mathrm{~g} \mathrm{~m}^{-2}\right)$, grain yield $\left(497 \mathrm{~g} \mathrm{~m}^{-2}\right)$, crop growth rate $\left(15.36 \mathrm{~g} \mathrm{~m}^{-2} \mathrm{~d}^{-1}\right)$, net assimilation rate $\left(4.24 \mathrm{~g} \mathrm{~m}^{-2} \mathrm{~d}^{-1}\right)$ were observed in the treatment having combination of two seedlings hill ${ }^{-1}$ and $200 \mathrm{~kg} \mathrm{Nha}^{-1}\left(\mathrm{PD}_{2} \mathrm{~N}_{200}\right)$. The agronomic and economic nitrogen and PAR use efficiencies were also higher in this treatment. In case of experiment-II, the highest biomass and grain yield were obtained in case of treatment having combination of two seedlings hill- ${ }^{-1}$ and $107.5 \mathrm{~cm}$ irrigation regime $\left(\mathrm{PD}_{2} \mathrm{I}_{107.5}\right)$. The irrigation application based water productivity ranged from $0.36 \mathrm{~kg} \mathrm{~mm}^{-3}$ to $0.61 \mathrm{~kg} \mathrm{~mm}^{-1}$, irrigation plus precipitation based water productivity ranged from $0.32 \mathrm{~kg}$ $\mathrm{mm}^{-3}$ to $0.55 \mathrm{~kg} \mathrm{~mm}^{-3}$ and evapotranspiration based water productivity ranged from $0.65 \mathrm{~kg} \mathrm{~mm}^{-3}$ to $0.84 \mathrm{~kg} \mathrm{~mm}^{-3}$ among 15 treatments combination of plant density and irrigation regimes. This study concludes that for increasing the benefits for the resource-poor growers, the integration of crop management practices is an optimum strategy to substantially increase the resources use efficiency under irrigated semiarid environment.
\end{abstract}

Keywords: irrigated rice, nutrient management, planting density, photosynthesis, yield potential

\section{Introduction}

Pakistan grows sufficient high quality rice to meet both domestic demand and for export. The majority of the rice is grown in rice-wheat cropping system. Rice is an important food and cash crop in Pakistan and ranks second after cotton (Gossypium hersutum L.). In 2008, rice contributed $5.9 \%$ in value added agriculture (VAA) and $1.35 \%$ in gross domestic product (GDP) and it was sown on $2.963 \mathrm{M}$ ha with total production of $6.952 \mathrm{M}$ tons and average yield of $2,346 \mathrm{~kg} \mathrm{ha}^{-1}$ (GOP, 2009). In Pakistan, rice is mainly produced in three main areas in three provinces; conventional (rice bowl) and non-conventional zone in Punjab; some parts in Sindh; and Swat valley in North Western Frontier Post with respect to areas under cultivation and production wise, respectively. In 2008, rice export figure for Pakistan is 2809 thousands tons including both basmati and non-basmati cultivars (GOP, 2009) and Fig. 1 shows the area, production, productivity and export of rice from 1974 to 2008.
In semiarid environmental conditions water and nutrients are two important input resources for harvesting good crop yield. In many regions of the world fresh water sources from both surface and ground water are shrinking up, causing a serious treat to the agricultural sector (Mahajan et al., 2009; Seckler et al., 1998; Tuong and Bhuiyan, 1994). In Asian countries per capita availability of water has declined by 40-60\% between 1955 and 1990 (Gleik, 1993; Hira et al., 2004; Ladha et al., 2003). However, situation is more adverse presently. Rice production in Asia is increasingly constrained by water (Arora, 2006). In Pakistan, rice production is under threat due to shrinking availability of fresh canal surface water due declining of storage capacity of dams. Precipitation is insufficient and concentrated in highly erratic temporally like other regional countries having moon soon season in summer (July-August) (GOP, 2009). Therefore, due to this ground water recharge is also under annul deficit and going deep and deep year by year and gradually pumping becoming unsustainable and costly due to rapid high prices of electricity and fuel. Rice crop in 
202

Pakistan is an important target for reduction in water use compared to other crops (Ahmad et al., 2009). Nitrogen is an important element being the structural and functional proteins, chlorophyll, nucleic acid and plays a pivotal role in crop development (Tisdale et al., 1990). The reason of nitrogen deficiency in Pakistani soils is the high cropping intensity and failure of sowing of leguminous crops in the existing cropping patterns (Ahmad et al., 2009) in addition to other losses, i.e., runoff, de-nitrification and volatilization. The major causes of low yield in Pakistan are deficiency of nutrients particularly nitrogen and less plant density because in Pakistan rice is manually transplanted by the highly un-skilled labor. There is an urgent need to study the integration of various crop management factors such as plant density, nitrogen rates and irrigation regimes to harvest the optimum rice yield under the existing resources situations.

Under interactive effects of various management practices, crop above-ground biomass can be analyzed as a function of the amount of radiation-absorbed by the foliage. In field crops, there is often a linear relationship between cumulative-intercepted photo-synthetically active radiation (PAR) and accumulated-biomass (Ceotto and Castelli, 2002; Gallagher and Biscoe, 1978; Kiniry et al.,

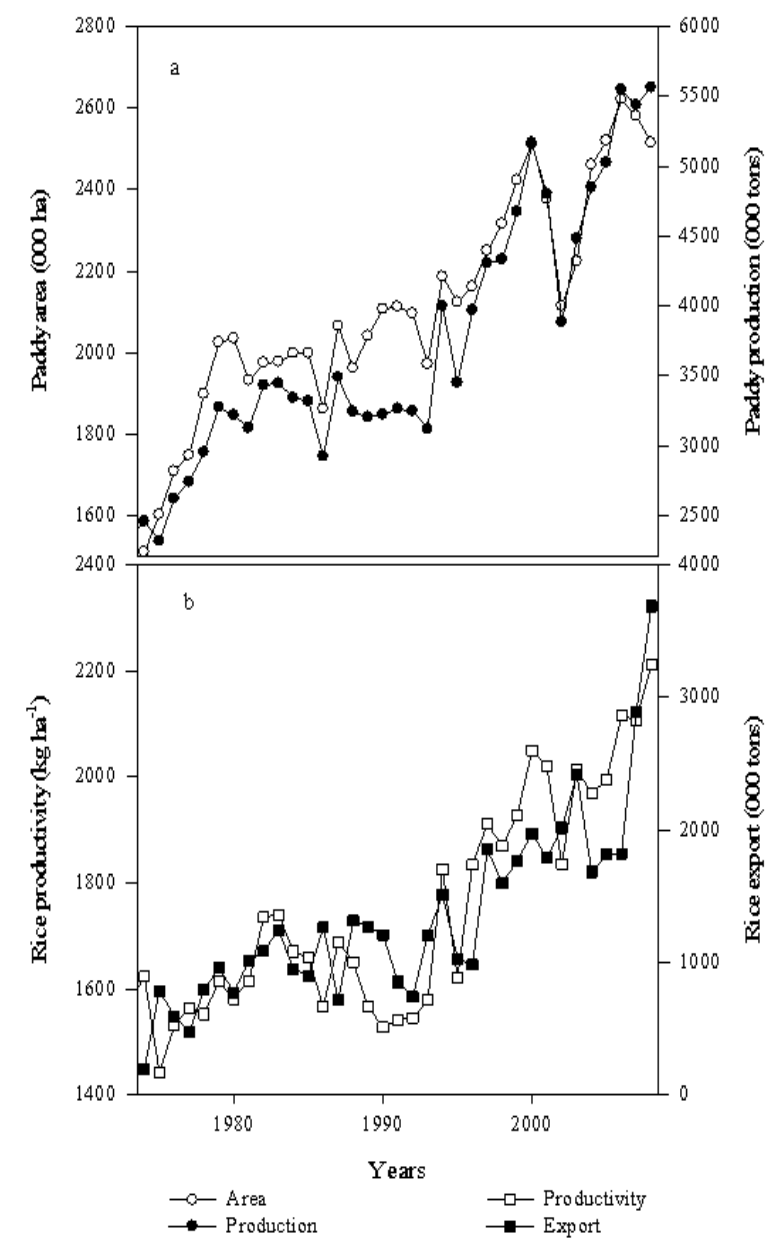

Fig. 1. Rice area, production (a), and productivity and export (b) in Pakistan from 1974-2008
1989; Loomis and Williams, 1963; Monteith, 1972; 1977; Russell et al., 1989; Sinclair and Muchow, 1999). Crop radiation use efficiency (RUE) is defined as the amount of biomass accumulated per unit solar radiation intercepted (Gallagher and Biscoe, 1978; Monteith, 1972; 1977). The fraction of intercepted-radiation may be estimated from zenith-angle, leaf area index (LAI) and leaf angle distribution (Ross, 1975). RUE is a simple measure of carbon assimilation integrated over the whole crop canopy. Crop photosynthetic rates, and hence RUE, is influenced by leaf nitrogen ( $\mathrm{g} \mathrm{N} \mathrm{m}^{-2}$ leaf area), when water is not limiting factor (Sinclair and Horie, 1989). The efficiency of the conversion of the intercepted-radiation into dry matter in cereals differs between pre and post-anthesis periods (Gregory et al., 1992; Kiniry et al., 1989). Therefore, determining RUE is an important approach for understanding crop growth and yield (Sinclair and Muchow, 1999).

Individual effects of crop management factors aboveground biomass has been applied to rice crop on a number of occasions. However, there are few studies that cover the integration dynamics of different management factors. The aims of this study were (1) to study integrated effects of plant density and nitrogen rates on biomass, grain yield, and nitrogen and PAR use efficiencies and (2) to study the integrated effects of plant density and irrigation regimes on biomass, grain yield, water productivity (grain yield/ irrigation applied; grain yield/irrigation + precipitation; grain yield/cumulative ET) and PAR use efficiency under irrigated semiarid environment.

\section{Materials and methods}

\section{Location description}

The field experiments were conducted in the experimental area of the Department of Agronomy, at University of Agriculture Faisalabad (UAF), Punjab, Paki$\operatorname{stan}\left(36.25^{\circ} \mathrm{N}, 73.09^{\circ} \mathrm{E}\right.$, and $184.4 \mathrm{~m}$ altitude from sea level). The experimental site is located in the rice-based cropping zone in the semiarid area of Pakistan. The soil is a Lyallpur clay loam (aridisol-fine-silty, mixed, hyperthermic Ustalfic, Haplarged in USDA classification and Haplic Yermosols in FAO classification) and physical and chemical characteristics are presented in Tab. 1 . The daily agro-meteorological information regarding maximum air temperature, minimum air temperature and precipitation and solar radiation were recorded by an automatic weather station located $500 \mathrm{~m}$ from the experimental field.

\section{Field data collection}

The experimental data that were collected from field experiments which were conducted during 2000 and 2001 in Faisalabad, Pakistan.

\section{Experiment 1}

Interactive effects of plant density and nitrogen rates were evaluated in experiment-I. There were three plant 
Tab. 1. Soil physical and chemical properties at $0-15 \mathrm{~cm}$ depth at the experimental site

\begin{tabular}{ccccccccc}
\hline Year & \multirow{2}{*}{ Site } & \multirow{2}{*}{ Soil classification } & Soil type & $\mathrm{pH}$ & $\begin{array}{c}\text { OM } \\
(\%)\end{array}$ & $\begin{array}{c}\text { Total } \\
\mathrm{N}(\%)\end{array}$ & $\begin{array}{c}\text { Available } \\
\mathrm{P}(\mathrm{ppm})\end{array}$ & $\begin{array}{c}\text { Available } \\
\mathrm{K}(\mathrm{ppm})\end{array}$ \\
\hline 2000 & FSD & Aridsol-fine-silty & Clay loam & 7.8 & 0.73 & 0.046 & 6.15 & 193 \\
2001 & FSD & Aridsol-fine-silty & Clay loam & 7.9 & 0.76 & 0.048 & 6.19 & 195 \\
\hline
\end{tabular}

FSD, Faisalabad; OM, organic matter

Tab. 2. Treatment combinations of plant density and nitrogen levels (Exp-I) and plant density and irrigation regimes (Exp-II) for field experimentation for rice cultivar 'Basmati-385' at Faisalabad, Pakistan during 2000 and 2001

\begin{tabular}{cccccc}
\hline \multicolumn{2}{c}{ Experiment-I } & \multicolumn{3}{c}{ Experiment-II } \\
\hline $\begin{array}{c}\text { Sr. } \\
\text { No. }\end{array}$ & $\begin{array}{c}\text { Treatment } \\
\text { combinations }\end{array}$ & $\begin{array}{c}\text { N levels } \\
\left(\mathrm{kg} \mathrm{ha}^{-1}\right)\end{array}$ & $\begin{array}{c}\text { PD } \\
\left(\begin{array}{c}\text { seedlings } \\
\text { hill-1 }\end{array}\right.\end{array}$ & $\begin{array}{c}\text { Irrigation } \\
\text { regimes } \\
(\mathrm{cm})\end{array}$ & $\begin{array}{c}\text { Treatment } \\
\text { combinations }\end{array}$ \\
\hline 1 & $\mathrm{PD}_{1} \mathrm{~N}_{0}$ & 0 & One & 62.5 & $\mathrm{PD}_{1} \mathrm{I}_{62.5}$ \\
2 & $\mathrm{PD}_{1} \mathrm{~N}_{50}$ & 50 & One & 77.5 & $\mathrm{PD}_{1} \mathrm{I}_{77.5}$ \\
3 & $\mathrm{PD}_{1} \mathrm{~N}_{100}$ & 100 & One & 92.5 & $\mathrm{PD}_{1} \mathrm{I}_{92.5}$ \\
4 & $\mathrm{PD}_{1} \mathrm{~N}_{150}$ & 150 & One & 107.5 & $\mathrm{PD}_{1} \mathrm{I}_{107.5}$ \\
5 & $\mathrm{PD}_{1} \mathrm{~N}_{200}$ & 200 & One & 122.5 & $\mathrm{PD}_{1} \mathrm{I}_{122.5}$ \\
6 & $\mathrm{PD}_{2} \mathrm{~N}_{0}$ & 0 & Two & 62.5 & $\mathrm{PD}_{2} \mathrm{I}_{62.5}$ \\
7 & $\mathrm{PD}_{2} \mathrm{~N}_{50}$ & 50 & Two & 77.5 & $\mathrm{PD}_{2} \mathrm{I}_{77.5}$ \\
8 & $\mathrm{PD}_{2} \mathrm{~N}_{100}$ & 100 & Two & 92.5 & $\mathrm{PD}_{2} \mathrm{I}_{92.5}$ \\
9 & $\mathrm{PD}_{2} \mathrm{~N}_{150}$ & 150 & Two & 107.5 & $\mathrm{PD}_{2} \mathrm{I}_{107.5}$ \\
10 & $\mathrm{PD}_{2} \mathrm{~N}_{200}$ & 200 & Two & 122.5 & $\mathrm{PD}_{2} \mathrm{I}_{122.5}$ \\
11 & $\mathrm{PD}_{3} \mathrm{~N}_{0}$ & 0 & Three & 62.5 & $\mathrm{PD}_{3} \mathrm{I}_{62.5}$ \\
12 & $\mathrm{PD}_{3} \mathrm{~N}_{50}$ & 50 & Three & 77.5 & $\mathrm{PD}_{3} \mathrm{I}_{77.5}$ \\
13 & $\mathrm{PD}_{3} \mathrm{~N}_{100}$ & 100 & Three & 92.5 & $\mathrm{PD}_{3} \mathrm{I}_{92.5}$ \\
14 & $\mathrm{PD}_{3} \mathrm{~N}_{150}$ & 150 & Three & 107.5 & $\mathrm{PD}_{3} \mathrm{I}_{107.5}$ \\
\hline 15 & $\mathrm{PD}_{3} \mathrm{~N}_{200}$ & 200 & Three & 122.5 & $\mathrm{PD}_{3} \mathrm{I}_{122.5}$ \\
\hline
\end{tabular}

densities, i.e., one seedling hill-1 ${ }^{-1}$ two seedlings hill ${ }^{-1}$ and three seedlings hill $^{-1}$, five nitrogen rates, i.e., 0, 50, 100, 150 , and $200 \mathrm{~kg} \mathrm{~N} \mathrm{ha}^{-1}$. The detailed descriptions of the 15 treatments having combinations of plant density and nitrogen rates are presented in Tab. 2. Additional details on plant sampling and observations can be found in Ahmad et al. $(2008 ; 2009)$.

\section{Experiment 2}

Interactive effects of plant density and irrigation regimes were studied in experiment-II. There were three plant densities, i.e., one seedling hill ${ }^{-1}$, two seedlings hill ${ }^{-1}$ and three seedlings hill-1 and five irrigation regimes, i.e., $62.5,77.5,92.5,107.5$, and $122.5 \mathrm{~cm}$. The detailed descriptions of the 15 treatments having combinations of plant density and irrigation regimes are presented in Tab. 2 .

\section{Experimental procedures}

Thirty-day-old rice cultivar ('Basmati-385') seedlings were transplanted manually in a half puddled field in standing water at $22.5 \mathrm{~cm}$ by $22.5 \mathrm{~cm}$ hill to hill and row to row distance in both experiments during both years. The nitrogen was applied in two equal splits through urea in both experiments and years. In exp-I, the nitrogen was applied as per treatment levels. In exp-II, the first dose $\left(75 \mathrm{~kg} \mathrm{ha}^{-1}\right)$ was applied during puddling before the final cultivation on 04 July in 2000 and 03 July in 2001. The second dose (75 $\mathrm{kg} \mathrm{ha}^{-1}$ ) was applied 22 days after transplanting (DAT) on 26 July in 2000 and 25 July in 2001. In addition, phosphorus and potassium $\left(\mathrm{P}_{2} \mathrm{O}_{5}\right.$ and $\mathrm{K}_{2} \mathrm{O} ; 65 \mathrm{~kg}$ each) in the form of single super phosphate (SSP), and potassium sulphate were also applied during puddling prior to final cultivation in both experiments during both years. Zinc at a rate of $25 \mathrm{~kg} \mathrm{ha}^{-1}$ was applied at puddling before final cultivation to avoid zinc deficiencies under standing water conditions in both experiments during both years. In Exp-I, total 16 irrigations were applied, while in Exp-II, irrigation water was applied as per treatments. The experimental plots in Exp-II were irrigated according to the respective treatments and as per schedules. Water in required amount was applied using a cutthroat flume $(90 \mathrm{~cm} \times 20 \mathrm{~cm})$. Time for application of required amount of water wad calculated using the Equation 1, [ $\mathrm{T}=\mathrm{Ad} / \mathrm{Q}]$, where $T$ is the time required for irrigation for each treatment; $A$ is the area to be irrigated; $d$ is the depth of irrigation application; and $Q$ is discharge or flow rate. The local agronomic practices for weed, disease, and pest control were uniform and crop was harvested in October. Additional details on crop management can be found in Ahmad et al. (2008; 2009).

\section{Calculations and derivations}

The following measurements and calculations were made following the prescribed standard procedures.

\section{Intercepted photosynthetically active radiation (IPAR;} $\left.M J m^{-2} d^{-1}\right)$

The daily total incident solar radiation (ISR) was estimated using Equation 2 suggested by the Ångström, (1924), $\left[\mathrm{SR}=\mathrm{SR}_{0}(\mathrm{a}+\mathrm{b} \mathrm{n} / \mathrm{N})\right]$, where $S R_{0}$ is the extraterrestrial radiation, $N$ is the maximum possible sunshine duration, $n$ is the measured sunshine duration, while $a$, and $b$ are constants. The data for $n$ was obtained from the observatory of the Department of Crop Physiology (CP), UAF, which is in the nearby block about $500 \mathrm{~m}$ from the experimental field.

\section{Fraction of intercepted radiation ( $F$ i)}

The $F i$ was estimated from leaf area index by using the Equation 3 (the exponential attenuation equation) suggested by Monteith and Elston (1983), $[\mathrm{Fi}=\{1-\exp (-\mathrm{k} \times$ LAI) $\}$, where $F i$ is the fraction of intercepted radiation, $k$ is extinction coefficient for total solar radiation. The PAR was calculated by multiplying 0.5 to the total incident radiation. The PAR intercepted $(\mathrm{Sa})$ was estimated by 
204

multiplying $F i$ values to their respective $S i$ values by using Equation 4 as suggested by Szeicz (1974), [ $\mathrm{Sa}=(\mathrm{Fi} \times \mathrm{Si})$ ], where $F i$ is the fraction of intercepted radiation and $S i$ is the total incident radiation. The cumulative intercepted phototosynthetically active radiation (CIPAR) was also estimated.

\section{Radiation use efficiency (RUE; $g M J^{-1}$ )}

The RUE for above-ground biomass $\left(\mathrm{RUE}_{\mathrm{AB}}\right)$ and grain yield $\left(R_{G E}\right)$ is the amount of above-ground biomass or grain yield produced per unit cumulative intercepted PAR, and was estimated by using Equation 5 suggested by Monteith (1977), $\left[\mathrm{RUE}_{\mathrm{AB}}=\mathrm{AB} / \mathrm{CIPAR}\right]$, or $\left[\mathrm{RUE}_{\mathrm{GY}}=\mathrm{GY} /\right.$ CIPAR], where, $A B$ and $G Y$ and CIPAR are the aboveground biomass, grain yield and cumulative intercepted photosynthetically active radiation, respectively.

\section{Agronomic nitrogen use efficiency (ANUE; $\mathrm{kg} \mathrm{kg}^{-1}$ )}

The ANUE was estimated by following the Equation 6 suggested by Saleem (1994). [ANUE $=\left(\mathrm{GY}_{\mathrm{F}}-\mathrm{GY}_{\mathrm{C}}\right) /$ Rate of $\mathrm{N}$ applied], where $G Y_{F}$ is the grain yield with $F$ rate of nitrogen fertilizer application and $G Y_{C}$ is the grain yield without nitrogen application.

\section{Economic nitrogen use efficiency (ENUE; rupees $\mathrm{kg}^{-1}$ )}

For benefits of the grower for decision making ENUE was also calculated by using the Equation 7 suggested by Saleem (1994) and Yadav (2003), [ENUE $=\left(\right.$ cost of GY, F $^{-}$ cost of $\mathrm{GY}_{\mathrm{C}}$ ) / cost of $\mathrm{N}$ fertilizer applied], where, cost of $G Y_{F}$ is the monetary return with particular rate of nitrogen fertilizer and $G Y_{C}$ is the monetary return without fertilizer application.

\section{Leaf area duration (LAD; days)}

The LAD is cumulative stay green time for assimilatory surface area (leaf area) and is calculated by Equation 8 suggested by the Watson (1947), $\left[\mathrm{LAD}=\left(\mathrm{LAI}_{1}+\mathrm{LAI}_{2}\right) / 2\right.$ $\left.\times\left(\mathrm{T}_{2}-\mathrm{T}_{1}\right)\right]$, where $L A I_{1}$ and $L A I_{2}$ were the leaf area indices at time $T_{1}$ and $T_{2}$, respectively. Cumulative $L A D$ was calculated at final harvest by adding all the $L A D$ values attained at different stages of rice crop.

\section{Crop growth rate (CGR; $\left.\mathrm{g} \mathrm{m}^{-2} \mathrm{~d}^{-1}\right)$}

The CGR was calculated by Equation 9 proposed by Hunt (1978), $\left[\mathrm{CGR}=\left(\mathrm{W}_{2}-\mathrm{W}_{1}\right) /\left(\mathrm{T}_{2}-\mathrm{T}_{1}\right)\right.$, where $W_{1}$ and $W_{2}$ are above-ground biomass at times $T_{1}$ and $T_{2}$, respectively.

\section{Net assimilation rate (NAR; $g m^{-2} d^{-1}$ )}

The mean NAR was estimated by following Equation 10 suggested by Hunt (1978), [NAR = AB / LAD], where $\mathrm{AB}$ and $\mathrm{LAD}$ are final above-ground biomass and cumulative leaf area duration, respectively.

\section{Estimation of water use}

The cumulative evapotranspiration (CET) was determined by multiplying potential Evapotranspiration (PET) with appropriate value of crop coefficient, which usually corresponds closely with the green crop cover as suggested by Dooreboss and Pruitt (1977). Daily Penman's PET was calculated by using standard program of "CROPWAT" developed by the FAO (1992).

\section{Water productivity (WP; $\mathrm{kg} \mathrm{m}^{-3}$ )}

The WP was calculated as above-ground biomass or grain yield produced per unit of water applied and was calculated by using the Equation 11, [I-WP = Grain yield / irrigation applied]. The irrigation + precipitation (I+PWP) was calculated by using the Equation $12,[\mathrm{I}+\mathrm{P}-\mathrm{WP}=$ Grain yield / irrigation applied + precipitation] and evapotranpiration (ET) based water productivity was also estimated by using the Equation 13, [ET-WP = Grain yield/ cumulative ET].

\section{Transpiration efficiency $\left(T E ; g^{-1}\right)$}

The TE for above-ground biomass was estimated by using Equation 11 suggested by Tanner and Sinclair (1983), $[\mathrm{TE}=\mathrm{AB} / \mathrm{T}]$, where $A B$ is the above-ground biomass and $T$ is the transpiration in $\mathrm{mm}$.

\section{Statistical analysis}

The data were statistically analyzed using MSTSTC software (Freed and Scott, 1986). Analysis of variance techniques were employed to test the overall significance of the data, while differences between treatment means were compared using the least significant difference (LSD) test at $\mathrm{P} \leq 0.5$ (Steel et al., 1997).

\section{Results}

\section{Growing environment}

The climate of the area is semiarid with an average annual maximum and minimum temperatures of $31.2^{\circ} \mathrm{C}$ and $17.2^{\circ} \mathrm{C}$, respectively, and annual precipitation ranges from 400 to $800 \mathrm{~mm}$. However, during the rice cropping season for local basmati (indica) varieties in Pakistan (June-October), the average seasonal maximum and minimum temperatures are $37.1^{\circ} \mathrm{C}$ and $24.3^{\circ} \mathrm{C}$, respectively. In general, in both 2000 and 2001 average maximum air temperature and average minimum temperature which were $16 \%$ and 29.2\% higher than their respective annual temperatures. Overall, $75 \%$ of the total annual precipitation occurs during the rice season (GOP, 2009). The monthly average solar radiation during the rice season ranges from 20 to $24.5 \mathrm{MJ} \mathrm{m}^{-2} \mathrm{~d}^{-1}$ versus an annual average range of $14-16 \mathrm{MJ}$ $\mathrm{m}^{-2} \mathrm{~d}^{-1}$, which is $30 \%$ and $35 \%$ higher than their respective annual values. The detailed weather data for rice seasons 2000 and 2001 are presented in Fig. 2.

\section{Experiment-I}

Rice biomass, grain yield, crop growth rate, net assimilation rate, agronomic and economic nitrogen and PAR use efficiencies as influenced by 15 treatment combinations of plant density and nitrogen rates during 2000 and 
Tab. 3. Final biomass, grain yield, crop growth rate, net assimilation rate, water productivity and PAR use efficiency of rice cultivar 'Basmati-385' as affected by plant density and nitrogen rates during 2000 and 2001 at Faisalabad, Pakistan

\begin{tabular}{|c|c|c|c|c|c|c|c|c|c|}
\hline Exp-I & \multirow{2}{*}{$\begin{array}{c}\text { Biomass } \\
\left(\mathrm{g} \mathrm{m}^{-2}\right)\end{array}$} & \multirow{2}{*}{$\begin{array}{c}\mathrm{GY} \\
\left(\mathrm{g} \mathrm{m}^{-2}\right)\end{array}$} & \multirow{2}{*}{$\begin{array}{c}\text { CGR } \\
\left(\mathrm{g} \mathrm{m}^{-2} \mathrm{~d}^{-1}\right)\end{array}$} & \multirow{2}{*}{$\begin{array}{c}\text { NAR } \\
\left(\mathrm{g} \mathrm{m}^{-2} \mathrm{~d}^{-1}\right)\end{array}$} & \multirow{2}{*}{$\begin{array}{l}\text { ANUE }_{\mathrm{AB}} \\
\left(\mathrm{kg} \mathrm{kg}^{-1}\right)\end{array}$} & \multirow{2}{*}{$\begin{array}{l}\text { ANUE }_{\mathrm{GY}} \\
\left(\mathrm{kg} \mathrm{kg}^{-1}\right)\end{array}$} & \multirow{2}{*}{$\begin{array}{l}\text { ENUE }_{\mathrm{GY}} \\
\left(\text { Rs. } \mathrm{kg}^{-1}\right)\end{array}$} & \multirow{2}{*}{$\begin{array}{l}\mathrm{RUE}_{\mathrm{AB}} \\
\left(\mathrm{g} \mathrm{MJ}^{-1}\right)\end{array}$} & \multirow{2}{*}{$\begin{array}{l}\mathrm{RUE}_{\mathrm{GY}} \\
\left(\mathrm{g} \mathrm{MJ}^{-1}\right)\end{array}$} \\
\hline Treatments & & & & & & & & & \\
\hline \multicolumn{10}{|c|}{2000} \\
\hline $\mathrm{PD}_{1} \mathrm{~N}_{0}$ & 964 & 276 & 10.63 & 3.62 & - & - & - & 0.98 & 0.28 \\
\hline $\mathrm{PD}_{1} \mathrm{~N}_{50}$ & 1046 & 309 & 11.34 & 3.71 & 10.27 & 3.03 & 3.65 & 1.03 & 0.31 \\
\hline $\mathrm{PD}_{1} \mathrm{~N}_{100}$ & 1150 & 344 & 12.48 & 3.78 & 11.40 & 3.41 & 3.92 & 1.10 & 0.33 \\
\hline $\mathrm{PD}_{1} \mathrm{~N}_{150}$ & 1233 & 409 & 13.32 & 3.83 & 12.27 & 4.07 & 4.29 & 1.15 & 0.38 \\
\hline $\mathrm{PD}_{1} \mathrm{~N}_{200}$ & 1260 & 423 & 13.59 & 3.75 & 12.56 & 4.22 & 4.47 & 1.15 & 0.39 \\
\hline $\mathrm{PD}_{2} \mathrm{~N}_{0}$ & 995 & 311 & 10.94 & 3.74 & - & - & - & 1.01 & 0.32 \\
\hline $\mathrm{PD}_{2} \mathrm{~N}_{50}$ & 1090 & 340 & 11.89 & 3.87 & 10.71 & 3.34 & 3.74 & 1.08 & 0.34 \\
\hline $\mathrm{PD}_{2} \mathrm{~N}_{100}$ & 1200 & 401 & 12.99 & 3.95 & 11.90 & 3.98 & 4.11 & 1.15 & 0.38 \\
\hline $\mathrm{PD}_{2} \mathrm{~N}_{150}$ & 1297 & 438 & 13.95 & 4.03 & 12.91 & 4.36 & 4.47 & 1.21 & 0.41 \\
\hline $\mathrm{PD}_{2} \mathrm{~N}_{200}$ & 1350 & 472 & 14.49 & 4.02 & 13.46 & 4.70 & 4.65 & 1.24 & 0.43 \\
\hline $\mathrm{PD}_{3} \mathrm{~N}_{0}$ & 985 & 313 & 10.84 & 3.70 & - & - & - & 1.00 & 0.32 \\
\hline $\mathrm{PD}_{3} \mathrm{~N}_{50}$ & 1074 & 336 & 11.72 & 3.81 & 10.54 & 3.30 & 3.78 & 1.06 & 0.33 \\
\hline $\mathrm{PD}_{3} \mathrm{~N}_{100}$ & 1173 & 375 & 12.71 & 3.86 & 11.63 & 3.72 & 4.12 & 1.12 & 0.36 \\
\hline $\mathrm{PD}_{3} \mathrm{~N}_{150}$ & 1274 & 423 & 13.72 & 3.96 & 12.67 & 4.21 & 4.39 & 1.19 & 0.39 \\
\hline $\mathrm{PD}_{3} \mathrm{~N}_{200}$ & 1312 & 446 & 14.10 & 3.90 & 13.07 & 4.44 & 4.52 & 1.20 & 0.41 \\
\hline \multicolumn{10}{|c|}{2001} \\
\hline $\mathrm{PD}_{1} \mathrm{~N}_{0}$ & 1026 & 287 & 11.25 & 3.83 & - & - & - & 1.23 & 0.34 \\
\hline $\mathrm{PD}_{1} \mathrm{~N}_{50}$ & 1113 & 326 & 12.12 & 3.91 & 10.93 & 3.20 & 3.84 & 1.29 & 0.38 \\
\hline $\mathrm{PD}_{1} \mathrm{~N}_{100}$ & 1224 & 362 & 13.22 & 3.99 & 12.14 & 3.59 & 4.11 & 1.36 & 0.40 \\
\hline $\mathrm{PD}_{1} \mathrm{~N}_{150}$ & 1313 & 431 & 14.11 & 4.03 & 13.06 & 4.29 & 4.51 & 1.42 & 0.47 \\
\hline $\mathrm{PD}_{1} \mathrm{~N}_{200}$ & 1342 & 446 & 14.40 & 3.95 & 13.37 & 4.45 & 4.69 & 1.43 & 0.47 \\
\hline $\mathrm{PD}_{2} \mathrm{~N}_{0}$ & 1060 & 327 & 11.58 & 3.96 & - & - & - & 1.27 & 0.39 \\
\hline $\mathrm{PD}_{2} \mathrm{~N}_{50}$ & 1161 & 353 & 12.59 & 4.07 & 11.40 & 3.46 & 3.86 & 1.34 & 0.41 \\
\hline $\mathrm{PD}_{2} \mathrm{~N}_{100}$ & 1278 & 423 & 13.76 & 4.16 & 12.67 & 4.20 & 4.31 & 1.42 & 0.47 \\
\hline $\mathrm{PD}_{2} \mathrm{~N}_{150}$ & 1381 & 461 & 14.79 & 4.24 & 13.74 & 4.59 & 4.69 & 1.50 & 0.50 \\
\hline $\mathrm{PD}_{2} \mathrm{~N}_{200}$ & 1438 & 497 & 15.36 & 4.23 & 14.33 & 4.95 & 4.88 & 1.53 & 0.53 \\
\hline $\mathrm{PD}_{3} \mathrm{~N}_{0}$ & 1057 & 329 & 11.55 & 3.94 & - & - & - & 1.27 & 0.39 \\
\hline $\mathrm{PD}_{3} \mathrm{~N}_{50}$ & 1143 & 354 & 12.41 & 4.01 & 11.22 & 3.47 & 3.94 & 1.32 & 0.41 \\
\hline $\mathrm{PD}_{3} \mathrm{~N}_{100}$ & 1249 & 360 & 13.47 & 4.07 & 12.38 & 3.57 & 4.24 & 1.39 & 0.40 \\
\hline $\mathrm{PD}_{3} \mathrm{~N}_{150}$ & 1356 & 446 & 14.54 & 4.16 & 13.49 & 4.44 & 4.6 & 1.47 & 0.48 \\
\hline $\mathrm{PD}_{3} \mathrm{~N}_{200}$ & 1396 & 470 & 14.95 & 4.11 & 13.91 & 4.68 & 4.74 & 1.49 & 0.50 \\
\hline
\end{tabular}

GY, Grain yield; CGR, Crop growth rate; NAR, Net assimilation rate; ANUE, Agronomic nitrogen use efficiency; ENUE, Economic nitrogen use efficiency; RUE, Radiation use efficiency

2001 are presented in Tab. 3. Averaged over the treatment combinations, the rice biomass ranged from $964 \mathrm{~g} \mathrm{~m}^{-2}$ to $1350 \mathrm{~g} \mathrm{~m}^{-2}$ during 2000 and $1026 \mathrm{~g} \mathrm{~m}^{-2}$ to $1438 \mathrm{~g} \mathrm{~m}^{-2}$ during 2001 (Tab. 3). The seasonal above-ground biomass accumulation for 15 treatment combinations of plant density and nitrogen rates is presented in Figs. 3 and 4 (a, c, and e) during 2000 and 2001. The Figs. 3 and 4 shows that the accumulation pattern of above-ground biomass was similar during both years and it was slow up to active tillering stage and then there was a linear increase followed by a slow increase phase. The comparatively superior performance of above-ground production at high rates of nitrogen responded positively and this was associated with higher leaf area duration integral of leaf area index over time. This enabled the crop plants in these treatments to intercept more of the available radiation and thus higher crop growth rate. Biscoe and Gallagher (1978) reported that higher crop growth rate is usually upon rapid expansion of leaf area index to intercept available radiation in the growing season. The grain yield ranged from $276 \mathrm{~g} \mathrm{~m}^{-2}$ to $472 \mathrm{~g} \mathrm{~m}^{-2}$ in 2000 and $287 \mathrm{~g} \mathrm{~m}^{-2}$ to $497 \mathrm{~g} \mathrm{~m}^{-2}$ in 2001 (Tab. 3). The treatment combination having two seedlings hill ${ }^{-1}$ and $200 \mathrm{~kg} \mathrm{~N} \mathrm{ha}{ }^{-1}$ produced the highest biomass and grain yield during both years. The crop growth rate ranged from $10.63 \mathrm{~g} \mathrm{~m}^{-2} \mathrm{~d}^{-1}$ to $14.49 \mathrm{~g} \mathrm{~m}^{-2} \mathrm{~d}^{-1}$ in 2000 and $11.25 \mathrm{~g} \mathrm{~m}^{-2} \mathrm{~d}^{-1}$ to $15.36 \mathrm{~g} \mathrm{~m}^{-2} \mathrm{~d}^{-1}$ in 2001 , while, the net assimilation rate ranged from $3.62 \mathrm{~g} \mathrm{~m}^{-2} \mathrm{~d}^{-1}$ to $4.03 \mathrm{~g} \mathrm{~m}^{-2} \mathrm{~d}^{-2}$ in 2000 and $3.83 \mathrm{~g} \mathrm{~m}^{-2} \mathrm{~d}^{-1}$ to $4.24 \mathrm{~g} \mathrm{~m}^{-2} \mathrm{~d}^{-1}$ in 2001 (Tab. 3). Agronomic nitrogen use efficiency for biomass ranged from $10.27 \mathrm{~kg}$ $\mathrm{kg}^{-1}$ to $13.46 \mathrm{~kg} \mathrm{~kg}^{-1}$ in 2000 and $10.93 \mathrm{~kg} \mathrm{~kg}^{-1}$ to 14.33 $\mathrm{kg} \mathrm{kg}^{-1}$ in 2001, while, the agronomic nitrogen use efficiency for grain yield ranged from $3.03 \mathrm{~kg} \mathrm{~kg}^{-1}$ to $4.70 \mathrm{~kg}$ 

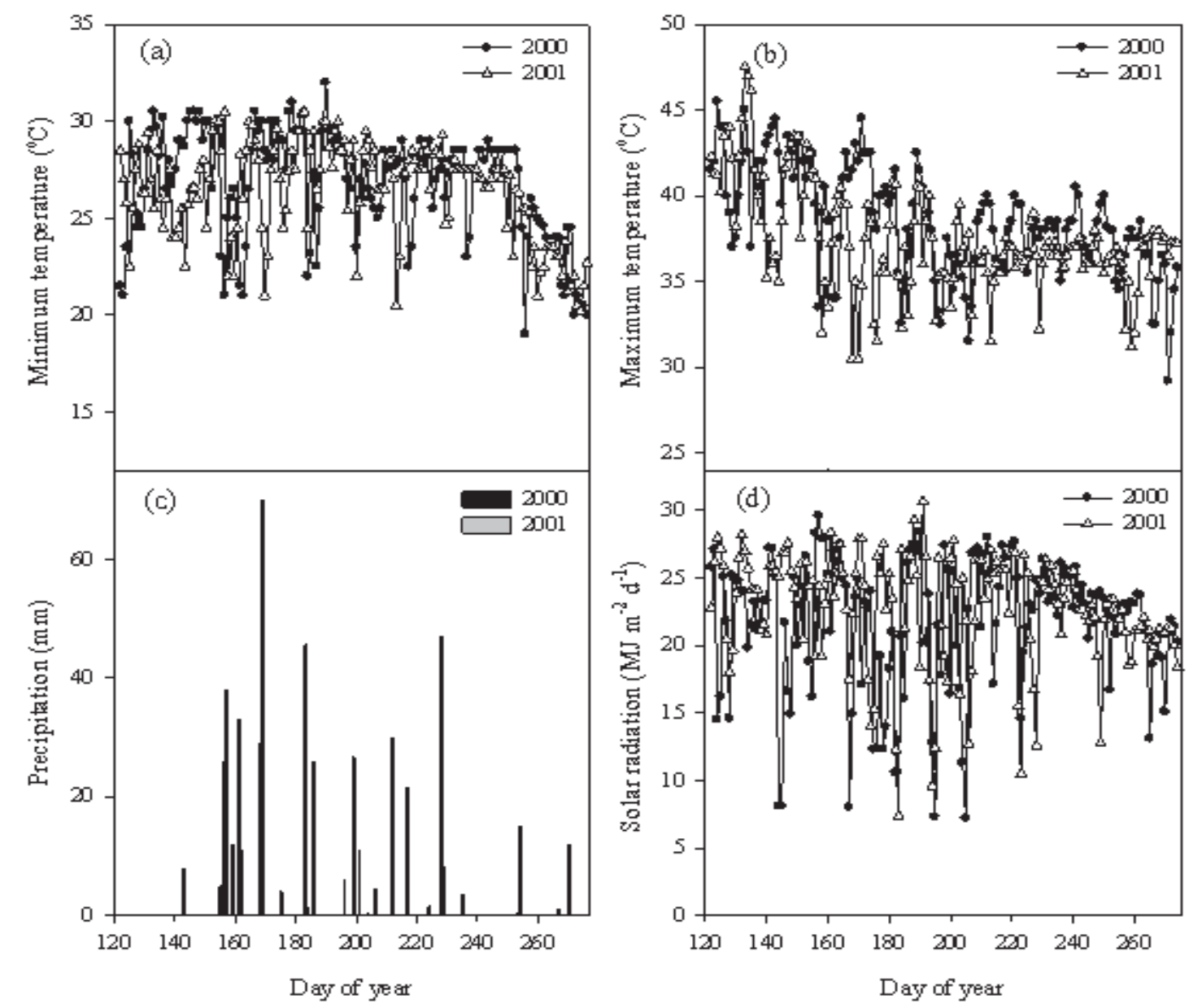

Fig. 2. Rice season daily weather conditions for Faisalabad, Pakistan: minimum temperature (a), daily maximum (b), daily precipitation (c) and daily solar radiation (d) for years 2000 and 2001

$\mathrm{kg}^{-1}$ in 2000 and $3.20 \mathrm{~kg} \mathrm{~kg}^{-1}$ to $4.95 \mathrm{~kg} \mathrm{~kg}^{-1}$ in 2001 . The economic nitrogen use efficiency ranged from 3.65 rupees $\mathrm{kg}^{-1}$ to 4.65 rupees $\mathrm{kg}^{-1}$ in 2000 and 3.84 rupees kg $\mathrm{kg}^{-1}$ to 4.88 rupees $\mathrm{kg}^{-1}$ in 2001 (Tab. 3). The highest agronomic and economic nitrogen use efficiencies were obtained in the treatment having combination of two seedlings hill ${ }^{1}$ and $200 \mathrm{~kg} \mathrm{~N} \mathrm{ha}^{-1}\left(\mathrm{PD}_{2} \mathrm{~N}_{200}\right)$. Total incident PAR was $1958 \mathrm{MJ} \mathrm{m}^{-2}$ in 2000 and $1974 \mathrm{MJ} \mathrm{m}^{-2}$ in 2001, out oh which about $52.8 \%$ and $45.2 \%$ were intercepted. The radiation use efficiency for biomass ranged from $0.98 \mathrm{~g} \mathrm{MJ}^{-1}$ to $1.24 \mathrm{~g} \mathrm{MJ}^{-1}$ during 2000 and $1.23 \mathrm{~g} \mathrm{MJ}^{-1}$ to $1.53 \mathrm{~g} \mathrm{MJ}^{-1}$ in 2001. The radiation use efficiency for grain yield ranged from $0.28 \mathrm{~g} \mathrm{MJ}^{-1}$ to $0.43 \mathrm{~g} \mathrm{MJ}^{-1}$ in 2000 and $0.34 \mathrm{~g} \mathrm{MJ}^{-1}$ to $0.53 \mathrm{~g} \mathrm{MJ}^{-1}$ in 2001 (Tab. 3). The highest values of the radiation use efficiencies were found in case of treatment having combination of two seedlings hill-1 and $200 \mathrm{~kg} \mathrm{~N}$ ha $^{-1}\left(\mathrm{PD}_{2} \mathrm{~N}_{200}\right)$.

\section{Experiment-II}

Rice biomass, grain yield, crop growth rate, net assimilation rate, irrigation, irrigation plus precipitation and evapotraspiration based water productivity and PAR use efficiencies as influenced by 15 treatment combinations of plant density and irrigation regimes during 2000 and 2001 are presented in Tab. 4. Averaged over the treatment combinations, the rice biomass ranged from $1174 \mathrm{~g} \mathrm{~m}^{-2}$ to $1448 \mathrm{~g} \mathrm{~m}^{-2}$ during 2000 and $1114 \mathrm{~g} \mathrm{~m}^{-2}$ to $1428 \mathrm{~g} \mathrm{~m}^{-2}$ during 2001 (Tab. 4). The seasonal above-ground biomass accumulation for 15 treatment combinations of plant density and irrigation regimes is presented in Figs. 3 and 4 (b, d, and f) during 2000 and 2001. The Figs. 3 and 4 shows that the accumulation pattern of above-ground biomass was slow during initial four or five weeks and then there was a linear increase. The treatment combinations having higher levels of irrigation application significantly and linearly increased above-ground biomass accumulation in both years. The grain yield ranged from $306 \mathrm{~g} \mathrm{~m}^{-2}$ to 471 $\mathrm{g} \mathrm{m}^{-2}$ in 2000 and $355 \mathrm{~g} \mathrm{~m}^{-2}$ to $497 \mathrm{~g} \mathrm{~m}^{-2}$ in 2001 (Tab. 4). The treatment combination having two seedlings hill ${ }^{-1}$ and $107.5 \mathrm{~cm}$ irrigation regime produced the highest biomass and grain yield during both years. The crop growth rate ranged from $9.72 \mathrm{~g} \mathrm{~m}^{-2} \mathrm{~d}^{-1}$ to $12.36 \mathrm{~g} \mathrm{~m}^{-2} \mathrm{~d}^{-1}$ in 2000 and $9.29 \mathrm{~g} \mathrm{~m}^{-2} \mathrm{~d}^{-1}$ to $12.27 \mathrm{~g} \mathrm{~m}^{-2} \mathrm{~d}^{-1}$ in 2001 , while, the net assimilation rate ranged from $4.41 \mathrm{~g} \mathrm{~m}^{-2} \mathrm{~d}^{-1}$ to $4.69 \mathrm{~g} \mathrm{~m}^{-2} \mathrm{~d}^{-2}$ in 2000 and $4.07 \mathrm{~g} \mathrm{~m}^{-2} \mathrm{~d}^{-1}$ to $4.63 \mathrm{~g} \mathrm{~m}^{-2} \mathrm{~d}^{-1}$ in 2001 (Tab. 4). Irrigation application water productivity ranged from 


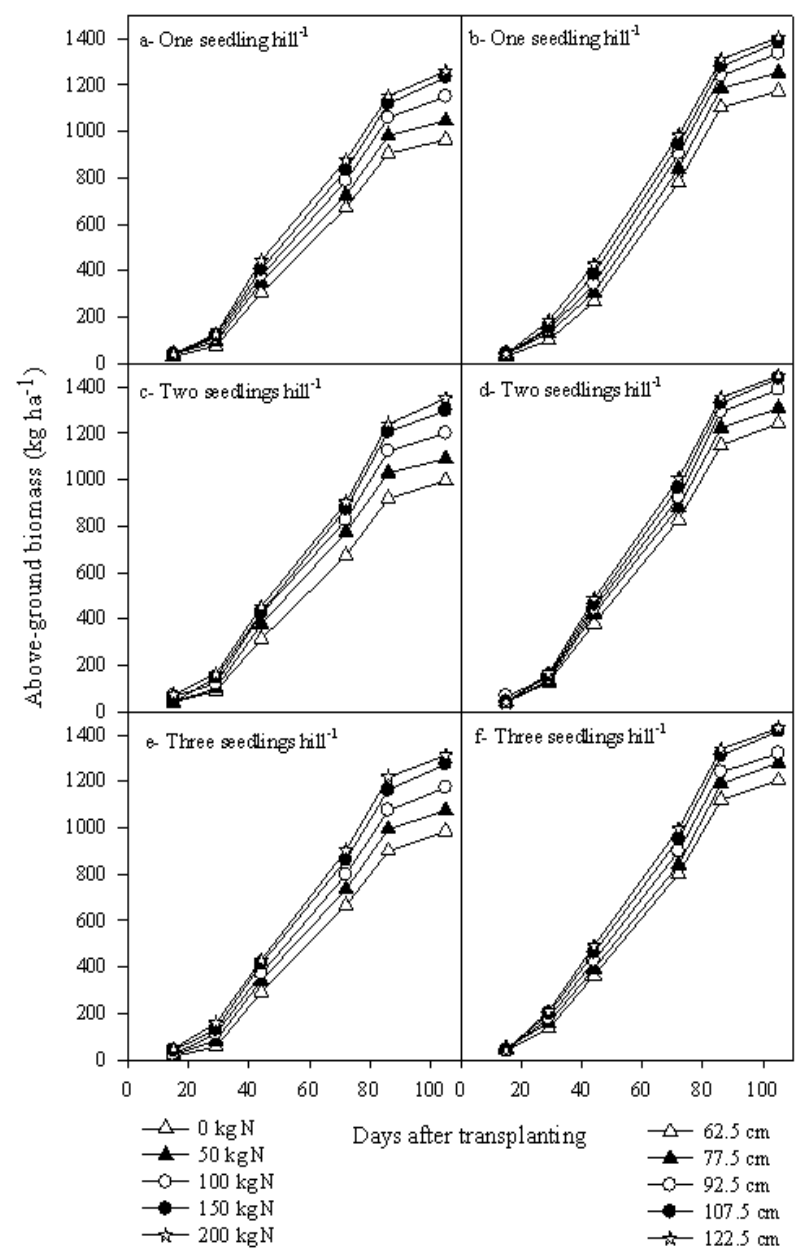

Fig. 3. Seasonal above-ground biomass accumulation as effected by plant density and nitrogen rates ( $a, c$, and e) and plant density and irrigation regimes $(b, d$, and $f$ ) of rice cultivar 'Basmati-385' at Faisalabad, Pakistan during 2000

$0.36 \mathrm{~kg} \mathrm{~mm}^{-3}$ to $0.59 \mathrm{~kg} \mathrm{~mm}^{-3}$ in 2000 and $0.34 \mathrm{~kg} \mathrm{~mm}^{-3}$ to $0.61 \mathrm{~kg} \mathrm{~mm}^{-3}$ in 2001. Total precipitation during both rice seasons was $115.7 \mathrm{~mm}$ in 2000 and $165 \mathrm{~mm}$ in 2001. Irrigation plus precipitation based water productivity ranged from $0.34 \mathrm{~kg} \mathrm{~mm}^{-3}$ to $0.52 \mathrm{~kg} \mathrm{~mm}^{-3}$ in 2000 and $0.34 \mathrm{~kg}$ $\mathrm{mm}^{-3}$ to $0.55 \mathrm{~kg} \mathrm{~mm}^{-3}$ in 2001. Evapotranspiration based water productivity ranged from $0.65 \mathrm{~kg} \mathrm{~mm}^{-3}$ to $0.78 \mathrm{~kg}$ $\mathrm{mm}^{-3}$ in 2000 and $0.73 \mathrm{~kg} \mathrm{~mm}^{-3}$ to $0.84 \mathrm{~kg} \mathrm{~mm}^{-3}$ in 2001 (Tab. 4). The water productivity values were higher at lower water regimes, while lower at higher water regimes. The radiation use efficiency for biomass ranged from 1.18 $\mathrm{g} \mathrm{MJ}^{-1}$ to $1.36 \mathrm{~g} \mathrm{MJ}^{-1}$ during 2000 and $1.31 \mathrm{~g} \mathrm{MJ}^{-1}$ to 1.56 $\mathrm{g} \mathrm{MJ}^{-1}$ in 2001, while, the radiation use efficiency for grain yield ranged from $0.31 \mathrm{~g} \mathrm{MJ}^{-1}$ to $0.44 \mathrm{~g} \mathrm{MJ}^{-1}$ in 2000 and $0.42 \mathrm{~g} \mathrm{MJ}^{-1}$ to $0.54 \mathrm{~g} \mathrm{MJ}^{-1}$ in 2001 (Tab. 4). The highest values of the radiation use efficiencies were found in case of treatment having combination of two seedlings hill ${ }^{-1}$ and $107.5 \mathrm{~cm}$ irrigation regime $\left(\mathrm{PD}_{2} \mathrm{I}_{107.5}\right)$.

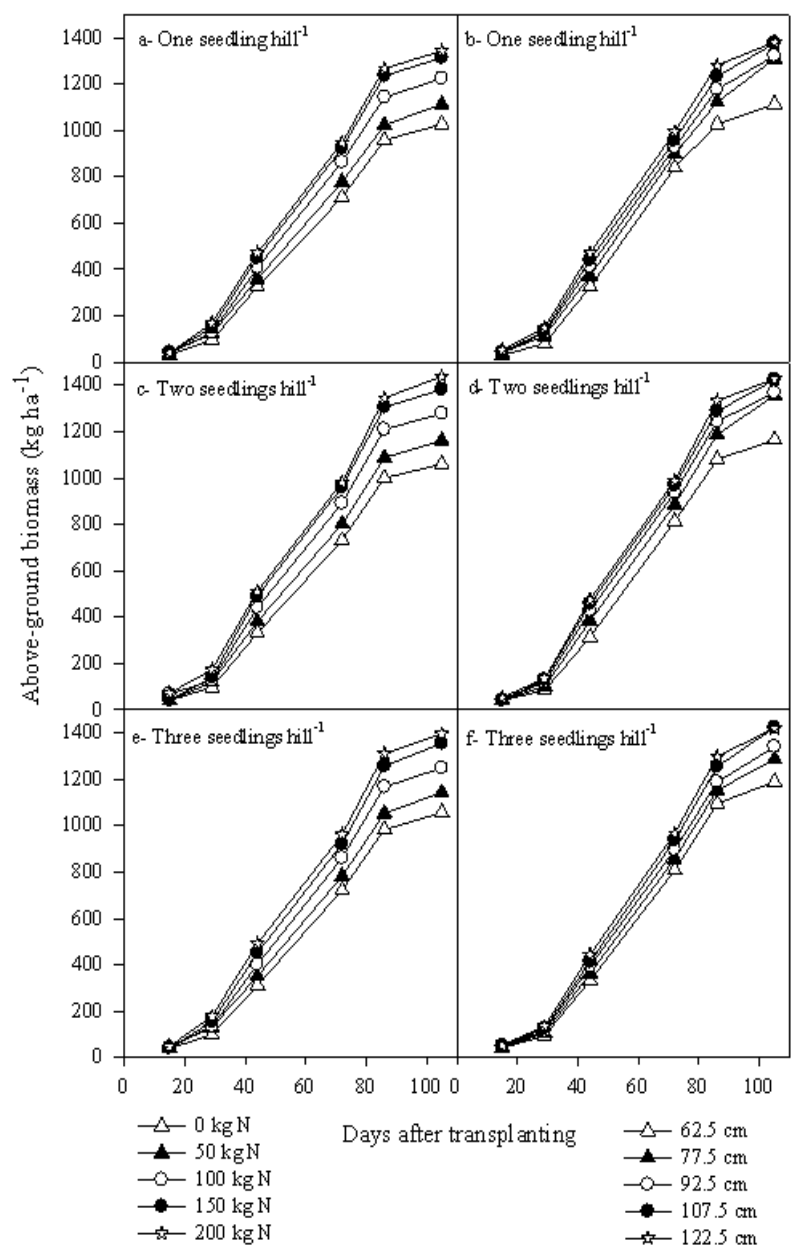

Fig. 4. Seasonal above-ground biomass accumulation as effected by plant density and nitrogen rates ( $a, c$, and e) and plant density and irrigation regimes ( $b, d$, and $\mathrm{f}$ ) of rice cultivar 'Basmati-385' at Faisalabad, Pakistan during 2001

\section{Discussion}

Among the improved cultural practices, number of seedling hill ${ }^{-1}$ can play important roles in boosting yield of rice (Hasanuzzaman et al., 2009a, b; Hossain et al., 2003). Number of seedlings hill-1 is important factor for successful rice production because it influences the tiller formation, solar radiation interception, total sunshine reception, nutrient uptake, rate of photosynthesis and other physiological phenomena and ultimately affects the growth and development of rice plant. In densely populated rice field the inter specific competition between the plants is high in which sometimes results in gradual shading and lodging and thus favour increased production of straw instead of grain (Faruk et al., 2009). Irrigation levels also an important factor for plant productivity which plays vital role in biomass accumulation, dry matter partitioning and grain development (Hasanuzzaman and Karim 2007; Hasanuz- 
208

Tab. 4. Final biomass, grain yield, crop growth rate, net assimilation rate, water productivity and PAR use efficiency of rice cultivar 'Basmati-385' as affected by plant density and irrigation regimes during 2000 and 2001 at Faisalabad, Pakistan

\begin{tabular}{|c|c|c|c|c|c|c|c|c|c|}
\hline Exp-II & \multirow{2}{*}{$\begin{array}{c}\text { Biomass } \\
\left(\mathrm{g} \mathrm{m}^{-2}\right)\end{array}$} & \multirow{2}{*}{$\begin{array}{c}\mathrm{GY} \\
\left(\mathrm{g} \mathrm{m}^{-2}\right)\end{array}$} & \multirow{2}{*}{$\begin{array}{c}\text { CGR } \\
\left(\mathrm{g} \mathrm{m}^{-2} \mathrm{~d}^{-1}\right)\end{array}$} & \multirow{2}{*}{$\begin{array}{c}\text { NAR } \\
\left(\mathrm{g} \mathrm{m}^{-2} \mathrm{~d}^{-1}\right)\end{array}$} & \multirow{2}{*}{$\begin{array}{c}\text { I-WP } \\
\left(\mathrm{kg} \mathrm{m}^{-3}\right)\end{array}$} & \multirow{2}{*}{$\begin{array}{c}\mathrm{I}+\mathrm{P}-\mathrm{WP} \\
\left(\mathrm{kg} \mathrm{m}^{-3}\right)\end{array}$} & \multirow{2}{*}{$\begin{array}{l}\text { ET-WP } \\
\left(\mathrm{kg} \mathrm{m}^{-3}\right)\end{array}$} & \multirow{2}{*}{$\begin{array}{l}\mathrm{RUE}_{\mathrm{AB}} \\
\left(\mathrm{g} \mathrm{MJ}^{-1}\right)\end{array}$} & \multirow{2}{*}{$\begin{array}{l}\mathrm{RUE}_{\mathrm{GY}} \\
\left(\mathrm{g} \mathrm{MJ}^{-1}\right.\end{array}$} \\
\hline Treatments & & & & & & & & & \\
\hline \multicolumn{10}{|c|}{2000} \\
\hline $\mathrm{PD}_{1} \mathrm{I}_{62.5}$ & 1174 & 306 & 9.72 & 4.41 & 0.49 & 0.44 & 0.65 & 1.18 & 0.31 \\
\hline $\mathrm{PD}_{1} \mathrm{I}_{77.5}$ & 1254 & 368 & 10.43 & 4.42 & 0.48 & 0.43 & 0.70 & 1.23 & 0.36 \\
\hline $\mathrm{PD}_{1} \mathrm{I}_{92.5}$ & 1336 & 408 & 11.25 & 4.52 & 0.44 & 0.41 & 0.72 & 1.29 & 0.39 \\
\hline $\mathrm{PD}_{1} \mathrm{I}_{107,5}$ & 1386 & 430 & 11.74 & 4.46 & 0.40 & 0.37 & 0.70 & 1.31 & 0.41 \\
\hline $\mathrm{PD}_{1} \mathrm{I}_{122.5}$ & 1406 & 437 & 12.04 & 4.41 & 0.36 & 0.34 & 0.69 & 1.31 & 0.41 \\
\hline $\mathrm{PD}_{2} \mathrm{I}_{62.5}$ & 1242 & 366 & 11.31 & 4.67 & 0.59 & 0.52 & 0.78 & 1.25 & 0.37 \\
\hline $\mathrm{PD}_{2} \mathrm{I}_{77.5}$ & 1307 & 391 & 11.05 & 4.60 & 0.51 & 0.46 & 0.74 & 1.28 & 0.38 \\
\hline $\mathrm{PD}_{2} \mathrm{I}_{92.5}$ & 1388 & 430 & 11.76 & 4.69 & 0.47 & 0.43 & 0.76 & 1.34 & 0.41 \\
\hline $\mathrm{PD}_{2} \mathrm{I}_{107,5}$ & 1436 & 464 & 12.24 & 4.62 & 0.43 & 0.40 & 0.76 & 1.36 & 0.44 \\
\hline $\mathrm{PD}_{2} \mathrm{I}_{122.5}$ & 1448 & 471 & 12.36 & 4.54 & 0.38 & 0.36 & 0.74 & 1.35 & 0.44 \\
\hline $\mathrm{PD}_{3} \mathrm{I}_{62.5}$ & 1204 & 350 & 10.03 & 4.53 & 0.56 & 0.50 & 0.74 & 1.22 & 0.35 \\
\hline $\mathrm{PD}_{3} \mathrm{I}_{77.5}$ & 1279 & 379 & 10.67 & 4.50 & 0.49 & 0.45 & 0.72 & 1.25 & 0.37 \\
\hline $\mathrm{PD}_{3} \mathrm{I}_{92.5}$ & 1320 & 407 & 11.09 & 4.46 & 0.44 & 0.41 & 0.72 & 1.27 & 0.39 \\
\hline $\mathrm{PD}_{3} \mathrm{I}_{107.5}$ & 1416 & 451 & 12.15 & 4.55 & 0.42 & 0.39 & 0.74 & 1.34 & 0.43 \\
\hline $\mathrm{PD}_{3} \mathrm{I}_{1225}$ & 1428 & 460 & 12.27 & 4.48 & 0.38 & 0.35 & 0.73 & 1.33 & 0.43 \\
\hline \multicolumn{10}{|c|}{2001} \\
\hline $\mathrm{PD}_{1} \mathrm{I}_{62.5}$ & 1114 & 355 & 9.29 & 4.07 & 0.57 & 0.48 & 0.78 & 1.31 & 0.42 \\
\hline $\mathrm{PD}_{1} \mathrm{I}_{77.5}$ & 1309 & 388 & 11.08 & 4.47 & 0.50 & 0.43 & 0.75 & 1.49 & 0.44 \\
\hline $\mathrm{PD}_{1} \mathrm{I}_{92.5}$ & 1322 & 430 & 11.20 & 4.33 & 0.46 & 0.41 & 0.77 & 1.48 & 0.48 \\
\hline $\mathrm{PD}_{1} \mathrm{I}_{1075}$ & 1376 & 454 & 11.65 & 4.29 & 0.42 & 0.38 & 0.75 & 1.51 & 0.50 \\
\hline $\mathrm{PD}_{1} \mathrm{I}_{122.5}$ & 1381 & 463 & 11.79 & 4.20 & 0.38 & 0.34 & 0.73 & 1.49 & 0.50 \\
\hline $\mathrm{PD}_{2} \mathrm{I}_{62.5}$ & 1165 & 384 & 9.64 & 4.26 & 0.61 & 0.52 & 0.84 & 1.37 & 0.45 \\
\hline $\mathrm{PD}_{2} \mathrm{I}_{77.5}$ & 1356 & 411 & 11.44 & 4.63 & 0.53 & 0.46 & 0.79 & 1.54 & 0.47 \\
\hline $\mathrm{PD}_{2} \mathrm{I}_{92.5}$ & 1368 & 454 & 11.67 & 4.49 & 0.49 & 0.43 & 0.81 & 1.53 & 0.51 \\
\hline $\mathrm{PD}_{2} \mathrm{I}_{107.5}$ & 1424 & 490 & 12.23 & 4.44 & 0.46 & 0.41 & 0.81 & 1.56 & 0.54 \\
\hline $\mathrm{PD}_{2} \mathrm{I}_{122.5}$ & 1428 & 497 & 12.27 & 4.34 & 0.41 & 0.37 & 0.79 & 1.55 & 0.54 \\
\hline $\mathrm{PD}_{3} \mathrm{I}_{62.5}$ & 1190 & 369 & 9.83 & 4.34 & 0.59 & 0.50 & 0.81 & 1.40 & 0.43 \\
\hline $\mathrm{PD}_{3} \mathrm{I}_{77.5}$ & 1287 & 400 & 11.39 & 4.58 & 0.52 & 0.45 & 0.77 & 1.53 & 0.46 \\
\hline $\mathrm{PD}_{3} \mathrm{I}_{92.5}$ & 1340 & 430 & 10.85 & 4.22 & 0.46 & 0.41 & 0.77 & 1.44 & 0.48 \\
\hline $\mathrm{PD}_{3} \mathrm{I}_{107.5}$ & 1423 & 475 & 12.22 & 4.44 & 0.44 & 0.40 & 0.78 & 1.56 & 0.52 \\
\hline $\mathrm{PD}_{3} \mathrm{I}_{1225}$ & 1421 & 486 & 12.19 & 4.32 & 0.40 & 0.36 & 0.77 & 1.54 & 0.53 \\
\hline
\end{tabular}

GY, Grain yield; CGR, Crop growth rate; NAR, Net assimilation rate; I-WP, Irrigation based water productivity; I+P-WP, Irrigation + precipitation based water productivity; ET-WP, ET based water productivity; RUE, Radiation use efficiency

zaman 2008; Hasanuzzaman et al., 2008). In rice N fertilization was also found to be very effective in rice biomass production and yield of rice (Hasanuzzaman et al., 2009; 2010). However, the biomass and grain yield values are less than other scientists (Arora et al., 2006; Katsura et al., 2008; Rashid et al., 2009; Zhang et al., 2009) working with rice in other regional countries, i.e., India, Bangladesh and China. The main reason might be the integration of genetic, crop management, and soil and environmental factors. Nitrogen $(\mathrm{N})$ is one of the most yield-limiting nutrients in lowland rice production around the world. Use of $\mathrm{N}$ efficient genotypes is an important complementary strategy in improving rice yield and reducing cost of production (Fageria and Barbosa Filho, 2001).

In this study, both the radiation use efficiency, biomass yield are greatly affected by $\mathrm{N}$ management which ulti- mately affected the final yield. The present results are in line with the findings of Katsura et al. (2008) and Zhang et al. (2009). However, they studied different management factors under different soil and environmental conditions in China. Kiniry et al. (1989) reported radiation use efficiency of $2.2 \mathrm{~g} \mathrm{MJ}^{-1}$ of intercepted PAR for a non-stressed rice crop. Water productivity express the capacity of plant to produce economic yield using per unit of applied water. As the plant density, $\mathrm{N}$ management and irrigation levels greatly affected the growth and yield of rice crop, it obviously improved the water productivity values.

Water productivity refers to the ratio between output (e.g. yield) and water use. However, the issue of most concern to this paper is not how to define water productivity, but rather how to measure it. In this study water productivity of rice is influenced by planting density and $\mathrm{N}$ levels. 
The water productivity values are line with the findings of scientists (Arora et al., 2006; Jalota et al., 2009; Mahajan et al., 2009; Rashid et al., 2009; Singh et al., 2001) working with rice in other countries, i.e., Bangladesh and India. The values for irrigation and precipitation based water productivity are in good agreement with the observed values of Rashid et al. (2009) under soil and climatic conditions of Bangladesh, Mahajan et al. (2009) in India and Kato et al. (2009) in Japan. However, they used other rice cultivars than in the present study.

\section{Conclusions}

The results indicate that studies having integration of management factors provide a wide window for decision making for higher resource use efficiencies for the benefits of the producers. The treatments having combinations of two seedlings hill- ${ }^{-1}$ and $200 \mathrm{~kg} \mathrm{~N}^{-1}\left(\mathrm{PD}_{2} \mathrm{~N}_{200}\right)$ or 107.5 $\mathrm{cm}$ irrigation regime $\left(\mathrm{PD}_{2} \mathrm{I}_{107.5}\right)$ are the most appropriate options for increasing the nitrogen, irrigation and radiation use efficiencies under irrigated semiarid environmental conditions. However, there is a need to validate technology through producer's participatory approach in diverse agro ecological conditions.

\section{References}

Ahmad S, Ahmad A, Ali H, Hussain H, Garcia y Garcia A, Khan MA, Zia-ul-Haq M, Hasanuzzaman M, Hoogenboom G (2012). Application of the CSM-CERES-Rice model for evaluation of plant density and irrigation management of transplanted rice for an irrigated semiarid environment. Irrig Sci doi: 10.1007/s00271-012-0324-6.

Ahmad S, Ahmad A, Soler CMT, Ali H, Zia-ul-Haq M, Anothai J, Hussain A, Hoogenboom G, Hasanuzzaman M (2012). Application of the CSM-CERES-Rice model for evaluation of plant density and nitrogen management of fine transplanted rice for an irrigated semiarid environment. Precision Agric 13:200-218.

Ahmad S, Ahmad A, Zia-ul-Haq M, Ali H, Khaliq T, Anjum MA, Khan MA, Hussain A, Hoogenboom G (2009a). Resources use efficiency of field grown transplanted rice (Oryza sativa L.) under irrigated semiarid environment. J Food Agric Environ 7:487-492.

Ahmad S, Hussain A, Ali H, Ahmad A (2005b). Grain yield of transplanted rice (Oryza sativa L.) as influenced by plant density and nitrogen fertilization. J Agric Soc Sci 1:212215.

Ahmad S, Hussain A, Ali H, Ashfaq A (2005a). Transplanted fine rice (Oryza sativa L.) productivity as affected by plant density and irrigation regimes. Int J Agric Bio 7:445-447.

Ahmad S, Zia-ul-Haq M, Ali H, Ahmad A, Khan MA, Khaliq T, Husnain Z, Hussain A, Hoogenboom G (2009b). Morphological and quality parameters of Oryza sativa L. as affected by population dynamics, nitrogen fertilization and irrigation regimes. Pak J Bot 41:1259-1269.

Ahmad S, Zia-ul-Haq M, Ali H, Shad SA, Ahmad A, Maqsood M, Khan MB, Mehmood S, Hussain A (2008). Water and radiation use efficiencies of transplanted rice (Oryza sativa L.) at different plant density and irrigation regimes under semi-arid environment. Pak J Bot 40:199-209.

Ångström A (1924). Solar and terrestrial radiation. Quart J R Meteorol Soc 50:121-125.

Arora VK (2006). Application of a rice growth and water balance model in an irrigated semi-arid subtropical environment. Agric Water Manage 83:51-57.

Arora VK, Gajri PR, Uppal HS (2006). Puddling, irrigation and transplanting-time effects on productivity of rice-wheat system on a sandy loam soil of Punjab. India. Soil Tillage Res 85:212-220.

Biscoe PV, Gallagher JN (1978). Physiological analysis of cereal yield. I. Production of dry matter. Agric Progress 53: 34-50.

Doorenbos J, Pruitt WO (1977). Guidelines for Predicting Crop Water Requirements, In: Irrigation and Drainage Paper 24, Food and Agricultural Organization of the United Nations, Rome, Italy.

Fageria NK, Barbosa Filho MP (2001). Nitrogen use efficiency in lowland rice genotypes. Commun Soil Sci Plant Anal 32: 2079-2089

FAO, Food and Agricultural Organization (1992). CROPWAT A computer programme for irrigation planning and management. FAO Irrigation and Drainage Paper 46, Rome, Italy.

Faruk MO, Rahman MA, Hasan MA (2009). Effect of seedling age and number of seedling per hill on the yield and yield contributing characters of BRRI Dhan33. Int J Sustain Crop Prod 4:58-61.

Freed RD, Scott DE (1986). MSTATC Crop and Soil Science Department, Michigan State University, MI, USA.

Gallagher JN, Biscoe PV (1978). Radiation absorption, growth and yield of cereals. J Agric Sci Camb 91:47-60.

Gerik TJ, Neely CL (1987). Plant density effects on main culm and tiller development of grain sorghum. Crop Sci 27:12251230.

Gleik PH (1993). Water Crisis: A Guide to the World's Fresh Water Resources. Pacific Institute for Studies in Development, Environment and Society. Stockholm Environment Institute, Oxford Univ Press, NY.

GOP, Government of Pakistan (2007). Economic Survey of Pakistan 2006-2007, Finance Division, Economic Advisory Wing, Finance Division, Govt Pakistan, 15-33 p.

GOP, Government of Pakistan (2008). Economic Survey of Pakistan 2007-2008, Economic Advisory Wing, Finance Division, Govt of Pakistan, 17-36 p.

GOP, Government of Pakistan (2009). Economic Survey of Pakistan 2008-2009, Economic Advisory Wing, Finance Division, Govt of Pakistan, 17-37 p.

Gregory PJ, Tennant D, Belford RK (1992). Root and shoot growth, and water and light use efficiency of barley and 
210 wheat crops grown on a shallow duplex soil in a Mediterranean-type environment. Aust J Agric Res 43:555-573.

Haefele SM, Siopongco JDLC, Boling AA, Bouman BAM, Tuong TP (2009). Transpiration efficiency of rice (Oryza sativa L.). Field Crops Res 111:1-10.

Hasanuzzaman M (2008). Siliqua and seed development in rapeseed (Brassica campestris L.) as affected by different irrigation levels and row spacings. Agric Conspec Sci 73:221226.

Hasanuzzaman M, Ahamed KU, Rahmatullah NM, Akhter N, Nahar K, Rahman ML (2010). Plant growth characters and productivity of wetland rice (Oryza sativa L.) as affected by application of different manures. Emir J Food Agric 22:4658.

Hasanuzzaman M, Karim MF (2007). Performance of rapeseed (Brassica campestris) cv. SAU sarisha-1 under different row spacings and irrigation level. Res J Agric Biol Sci 3:960-965.

Hasanuzzaman M, Karim MF, Ullah MJ (2008). Growth dynamics of rapeseed (Brassica campestris L.) cv. SAU Sarisha-1 as influenced by irrigation levels and row spacings. Aust J Basic Appl Sci 2:794-799.

Hasanuzzaman M, Nahar K, Alam MM, Hossain MZ, Islam MR (2009). Response of transplanted rice to different application methods of urea fertilizer. Int J Sustain Agric 1:1-5.

Hasanuzzaman M, Nahar K, Roy TS, Rahman ML, Hossain MZ, Ahmed JU (2009). Tiller dynamics and dry matter production of transplanted rice as affected by plant spacing and number of seedling per hill. Acad J Plant Sci 2:162-168.

Hasanuzzaman M, Rahman ML, Roy TS, Ahmed JU, Zobaer ASM (2009). Plant characteristics, yield components and yield of late transplanted aman rice as affected by plant spacing and number of seedling per hill. Adv Biol Res 3:201207.

Hira GS, Jalota SK, Arora VK (2004). Efficient Management of Water Resources for Sustainable Cropping in Punjab. Technical Bulletin. Department of Soils, Punjab Agricultural University. Ludhiana, India, 20 p.

Hossain MS, Mamun AA, Basak R, Newaj MN, Anam MK (2003). Effect of cultivar and spacing on weed infestation and performance of transplanted aman rice in Bangladesh. Pakistan J Agron 2: 169-178.

Hunt R (1978). Plant growth analysis. Edwards Arnold, U.K. 26-28 p.

Jalota SK, Singh KB, Chahal GBS, Gupta RK, Chakraborty S, Sood A, Ray SS, Panigrahy S (2009). Integrated effect of transplanting date, cultivar, and irrigation on yield, water saving and water productivity of rice (Oryza sativa L.) in Indian Punjab. Field and simulation study. Agric Water Manage 96:1096-1104.

Kato Y, Okami M, Katsura K (2009). Yield potential and water use efficiency of aerobic rice (Oryza sativa L.) in Japan. Field Crops Res 113:328-334.

Katsura K, Maeda S, Lubis I, Horie T, Cao W, Shiraiwa T (2008). The high yield of irrigated rice in Yunnan, China 'A cross-location analysis. Field Crops Res 107:1-11.

Kinry JR, Jones CA, O’Toole JC, Blanchet R, Cabelguenne M, Spanel DA (1989). Radiation-use efficiency in biomass accumulation prior to grain-filling for five five grain-crops. Field Crops Res 20:51-64.

Kinry JR, Landivar JA, Witt M, Gerik TJ, Cavero J, Wade LJ (1998). Radiation-use efficiency response to vapour pressure deficit for maize and sorghum. Field Crops Res 56:265270.

Ladha JK, Pathak H, Tirol-Padre A, Dawe D, Gupta RK (2003). Productivity trends in intensive rice-wheat cropping systems in Asia. In: Ladha, J.K., Hill, J.E., Duxbury, J.M., Gupta, R.K., Buresh, R.J. (Eds.), Improving the Productivity ans Sustainability of Rice-Wheat System: Issues and Impacts. ASA, Inc., ASA Special Publication 65, Madison, 45-76 p.

Loomis RS, Williams WA (1963). Maximum crop productivity: An estimate. Crop Sci 3:67-72.

Mahajan G, Bharaj TS, Timsina J (2009). Yield and water productivity of rice as affected by time of planting in Punjab, India. Agric. Water Manage 96:525-532.

Monteith JL (1965). Light distribution and photosynthesis in field crops. Ann Bot 29:17-37.

Monteith JL (1972). Solar radiation and productivity in tropical ecosystems. J Appl Ecol 747-294.

Monteith JL (1977). Climate and the efficiency of crop production in Britain. Philos Trans R Soc Lond 281:277-294.

Monteith JL (1994). Validity of the correlation between intercepted radiation and biomass. Agric For Meteorol 68:213220.

Monteith JL, Elston JF (1983). Performance and productivity of foliage in the field. In: The Growth and Functioning of Leaves (Eds.) J.E. Dale, F.L. Milthorpe. Cambridge University Press, Butterworth, London, 499-518 p.

Rashid MH, Alam MM, Khan MAH, Ladha JK (2009). Productivity and resource use of direct-(drum)-seeded and transplanted rice in puddled soils in rice-rice and rice-wheat ecosystems. Field Crops Res 113:274-281.

Ross J (1975). Radiative transfer in plant communities. In: Monteith, J.L. (Ed.), Vegetation and the Atmosphere, volume 1: Principles. Academic Press, London, p. 278.

Russell G, Jarvis PG, Monteith JL (1989). Absorption of radiation by canopies and stand growth. In: Russell, G. (Ed.), Plant Canopy: Their Growth, Form and Functions. Cambridge University Press, Cambridge, 21-39 p.

Saleem MT (1994). Efficient use of plant nutrients, In: Efficient Use of Plant Nutrients, Proceedings of Fourth National Congress of Soil Science, Islamabad, 2-12 p.

Seckler D, Amarasinghe U, Molden D, De Silva R, Barker R (1998). World Water Demand ans Supply, 1990 to 2025: Scenarios and Issues. Res. Rep. 19. Int. Water Management Inst., Colombo, Sri Lanka.

Sinclair TR, Horie T (1989). Leaf nitrogen, photosynthesis, and crop radiation use efficiency: a review. Crop Sci 29, 90-98. 
Sinclair TR, Muchow RC (1999). Radiation use efficiency. Adv Agron 65:215-265.

Singh KB, Gajri PR, Arora VK (2001). Modeling the effects of soil and water management practices on the water balance and performance of rice. Agric. Water Manage 49:77-95.

Steel RGD, Torrie JH, Dickey DA (1997). Principles and Practices of Statistics, A Biometric Approach, $3^{\text {rd }}$ Eds. McGraw Hill, Int. Book Co., Inc., Singapore.

Szcicz G (1974). Solar radiation for plant growth. J Appl Ecol 11: 617-636.

Tisdale SL, Nelson WL, Beaton JD (1990). Soil Fertility and Fertilizers. MacMillan Publishing Company NY, 60-62 p.

Toung TP, Bhuiyan SI (1994). Innovations towards improving water-use efficiency in rice. Paper presented at the World Bank's 1994. Water Resources Seminar, December 13-15, 1994. Landsdowne, VA, USA.
Watson DJ (1947). Comparative physiological studies on the growth of field crops. 1. Variation in net assimilation rate and leaf area between species and varieties and within and between years. Ann Bot 11:41-76.

Watson DJ (1952). The physiological basis of variation in yield. Adv Agron 4:101-145.

Watson DJ (1958). The dependence of net assimilation rate on leaf area index. Ann Bot 22:37-54.

Yadav RL (2003). Assessing on-farm efficiency and economics of fertilizer N, P and K in rice- wheat systems of India. Field Crops Res 81:39-51.

Zhang Y, Tang Q, Zou Y, Li D, Qin J, Yang S, Chen L, Xia B, Peng S (2009). Yield potential and radiation use efficiency of "super" hybrid rice grown under subtropical conditions. Field Crops Res 114:91-98. 